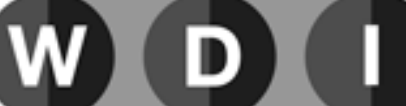

William Davidson Institute

AT THE UNIVERSITY OF MICHIGAN

\title{
YOUTH EMPLOYMENT IN AFRICA: NEW EVIDENCE AND POLICIES FROM SWAZILAND
}

\author{
By: Zuzana Brixiová and Thierry Kangoye
}

William Davidson Institute Working Paper Number 1052

June 2013 


\title{
YOUTH EMPLOYMENT IN AFRICA: NEW EVIDENCE AND POLICIES FROM SWAZILAND
}

\author{
Zuzana Brixiová and Thierry Kangoye ${ }^{1}$
}

\begin{abstract}
Drawing on the 2007 and 2010 Swaziland Labor Force Surveys, this paper provides first systematic evidence on recent youth employment challenges in Swaziland, a small, landlocked, middle-income country with one of the highest youth unemployment rates in Africa. The paper first documents the various labor market disadvantages faced by the Swazi youth, such as high unemployment and discouragement, and how they changed from 2007 to 2010. A multinomial logit regression analysis is then carried out to analyze the socio-economic drivers of the unfavorable youth labor market outcomes on the supply side. Since many of the factors that can unlock the employment potential of the Swazi youth are on the demand side of the labor market, the paper examines the barriers to job creation and youth entrepreneurship. It concludes with experiences of other countries that could inform design of more effective interventions for youth employment in Swaziland.
\end{abstract}

JEL classification: J11, J08, L26, O11

Key words: youth employment and entrepreneurship, multivariate analysis, policies, Africa

\footnotetext{
${ }^{1}$ The authors are with the African Development Bank. They are particularly thankful to Mthuli Ncube, the Chief Economist and Vice President of the AfDB, for suggesting this topic and stimulating discussions. Special thanks go to Musinga T. Bandora from the United Nations for support in the early stages of the paper and to Robert Fakudze from the Swaziland Ministry of Labor for data and discussing policies. The authors also thank Temi Abimbola, Marva Corley-Coulibaly, Nomusa Dlamini-Tibane, Kumiko Imai, Thandy Khumalo, Zodwa Mabuza, Mateus Magala, and Neil Rankin for comments. Earlier versions were presented at the Wits University, the 2012 CSAE Conference (Oxford), the 2012 African Economic Conference (Kigali) and the 2013 ASSA meetings (San Diego). Financial support from the Wits University is gratefully acknowledged. The views expressed are those of the authors and do not necessarily reflect those of the AfDB. E-mail addresses: z.brixiova@afdb.org; t.kangoye@afdb.org.
} 


\section{Introduction}

Swaziland, a small land-locked country in Southern Africa, seems to be caught in the middle income trap. Despite its favorable location, mild climate, and a relatively diversified production base, it has been one of the slowest growing economies in Africa for almost two decades. Even with 'rising' Africa, Swaziland's average annual growth during 2000 - 2012 was a mere 2.3 percent - well below the 5.8 percent average posted by the continent. The country's real GDP per capital is projected to decline in both 2013 and 2014 (African Development Bank et al., 2013). ${ }^{2}$

Swaziland's sluggish growth has been accompanied by high unemployment, poverty and inequality. The country's first two (2007 and 2010) labor force surveys revealed unemployment rate of 26.3 and 26.8 percent of the labor force, respectively - some of the highest rates even among Africa's middle income countries. ${ }^{3}$ Marked differences across subgroups have emerged, with youth, women, and less educated workers disproportionally impacted. The employment challenge has been amplified by high rates of discouragement, especially among young women and the rural population.

The 2011 'Poverty Maps’ (Government of Swaziland, 2011) have highlighted the negative links between poverty and employment and raised concern about the implications of low employment on poverty and people's welfare. With the majority of Swazis relying mainly on income from formal sector employment for their livelihoods, it is not surprising that in 2010 the nation-wide poverty encompassed 63 percent of the population. Poverty has been linked to weak social indicators, exacerbated by a high prevalence of HIV (UNDP, 2013).

The labor market situation has worsened in 2011 and 2012 by the delayed impact of the global financial crisis, transmitted to the economy mostly through the collapse of revenues from the Southern Africa Custom Union (SACU). Because of the subsequent liquidity crunch, the government froze public sector hiring and accumulated arrears to the small and medium enterprises (SMEs). The crisis was transferred to households mostly through cuts in jobs, wages and work hours, and firm closures in the private sector (UN Swaziland, 2012).

Against this background Swaziland faces a major youth employment challenge. This paper documents the labor market disadvantages faced by Swazi youth. It also analyzes changes in these disadvantages over time and discusses options for addressing them. At about 50 percent of the labor force, youth unemployment in Swaziland is high and unsustainable, as the 2011 experiences in North Africa showed. With the underdeveloped private sector and the lack of productive jobs, structural transformation is among key policy priorities. ${ }^{4}$ The government has undertaken some steps to address the youth employment situation, but is yet to develop a comprehensive approach to tackle it.

\footnotetext{
${ }^{2}$ Felipe (2012) classified Swaziland among 22 countries currently caught in the low middle-income trap. Swaziland and Africa's growth during 2000 - 2012 was calculated based on data in the AfDB database.

3 Throughout the paper, data are un-weighted and reflect the actual information in the surveys, with the urban population somewhat overrepresented relative to its actual share in the total population. The re-weighted unemployment is thus slightly higher, reaching about 28 percent of the labor force in both 2007 and 2010 according to the Swaziland Ministry of Labor.

${ }^{4}$ In low income countries the main employment issue is working poverty. In both low and middle income countries sources of youth employment need to come mostly on structural transformation (Page 2012).
} 
Our paper contributes to the literature on labor markets in Southern Africa by providing first systematic evidence on the youth labor market in Swaziland, a country with particularly high youth unemployment rates. By utilizing the first two (2007 and 2010) Swaziland Labor Force Surveys and shedding light on the trends, scale, and forms of youth labor market disadvantages, the paper provides evidence for policymaking. ${ }^{5}$ It also illustrates the first-round impact of the global financial crisis on the labor market of a small, open, land-locked economy. The paper can be particularly relevant for other small middleincome countries in Southern Africa that aim to reach inclusive growth in the midst of fluctuating SACU revenues, high unemployment, income inequality, and HIV rates (Jauch, 2011).

Besides Southern Africa, the paper contributes to the ongoing more general analysis and policy debates on youth employment in Africa. First, reliable labor market data from African countries are still relatively scarce, and until recently none was available for Swaziland. Second, with the global financial crisis turning into a job crisis and impacting youth disproportionally, youth employment became a key global policy issue (AfDB et al. 2012, ILO, 2012; World Bank, 2013a). In Africa, where youth employment is a long-standing challenge, policymakers have put even higher priority on creating jobs for their youth and on entrepreneurship. ${ }^{6}$ Our paper adds to these debates insights from a small landlocked country with one of the highest youth unemployment rates in Africa and globally.

The paper is organized as follows. Section II outlines main features of the Swazi labor market, with focus on youth. Section III analyzes factors behind the youth employment challenge in Swaziland, while Section IV discusses policy options. Section V concludes.

\section{Key Features of the Swazi Labor Market}

\section{a. Overall Situation}

This section outlines the main features of the Swazi labor market based on the country's Labor Force Surveys 2007 and 2010, including: (i) high unemployment and its long duration; (ii) declining employment and labor force participation rates; and (iii) unemployment impacting disproportionally youth, women, and the less educated.

\section{(i) High overall unemployment, with long duration}

Based on the labor force surveys' data, Swaziland's overall unemployment rate reached 26.3 percent and 26.8 percent of the labor force in 2007 and 2010, respectively. At those times, the country's unemployment rate, which rose markedly since the mid-1990s, was among the highest in Africa's middle income countries. In the context of Southern Africa, high unemployment is not unique to Swaziland, but prevails also in the other middle income countries in the region (Table 1).

Another notable feature of the labor market in Swaziland is the long unemployment and/or underemployment duration. For example, about 80 percent of respondents in the 2007 Swaziland Labor

\footnotetext{
${ }^{5}$ The methodology for the 2007 and 2010 Swaziland labor force surveys followed the ILO standards. The sample consisted of over 3,000 households and more than 13,000 individuals.

${ }^{6}$ An initiative on 'Job Creation for Youth in Africa' has been launched between the African Union, Economic Commission for Africa, African Development Bank and the International Labour Organization.
} 
Force Survey indicated that they were available for work for over a year, and more than half of respondents were available for more than two years.

Table 1. Unemployment and Labor Force Participation in Selected Countries

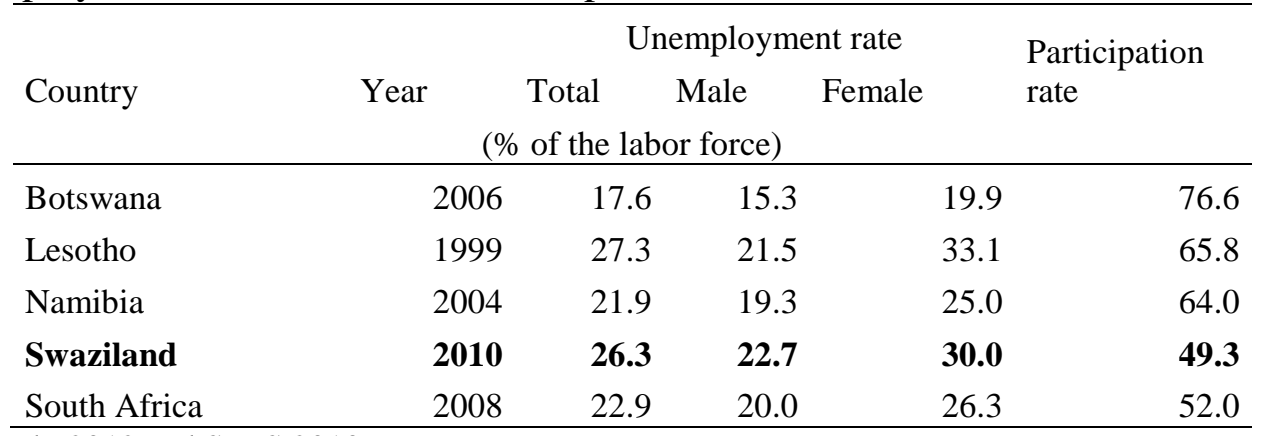

Source: AfDB et al., 2012 and SLFS 2010.

\section{(ii) Declining employment and labor force participation rates}

Even though the official unemployment rate changed only marginally between 2007 and 2010, the labor market situation deteriorated and employment (which encompasses both the formal and informal sector) fell. ${ }^{7}$ In fact, employment rates decreased in all major age categories, and markedly in some age groups (above 35 years) and among men (Figure 1).

The seemingly stable unemployment rate thus masked a decline in labor force participation. Indeed, if the 2010 labor force participation stayed at the 2007 level (53.4 percent of working age population rather than 49.3 percent), the unemployment rate would reach 33.2 percent of the labor force rather than 26.3 percent. Moreover, if all discouraged workers were included in the labor force, the 2010 unemployment rate would rise further to 37 percent.

\section{(iii) Unemployment falls disproportionally on several groups}

Unemployment in Swaziland is especially widespread among: (i) women, (ii) the less educated, and (iii) youth. This section points out challenges faced by these groups.

\section{(1) Women}

In absolute terms women fare worse than men in the Swazi labor market. Women were more affected by unemployment and had lower labor force participation than men in both 2007 and 2010. However, men were more impacted by the first round effect of the global financial crisis through withdrawal from the labor force and lower employment rates (Table 2). ${ }^{8}$

\footnotetext{
7 The deterioration was in part because of the negative impacts of the global financial crisis on selected sectors (e.g., manufacturing). At least 3,000 workers lost jobs in the textile sector alone in 2009 (SACU, 2011).

${ }^{8}$ Kangoye and Brixiova (2013) elaborate on scope and the drivers of the gender gap in the Swazi labor market.
} 
Figure 1. Swaziland: Labor market outcomes in 2007 and 2010, by age and gender

1a. Ages 15 - 24 (in percent)

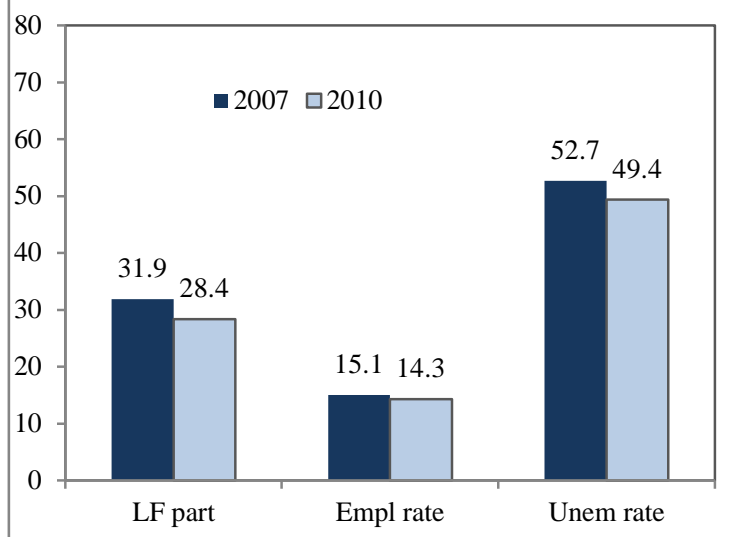

1c. Ages 35 years + (in percent)

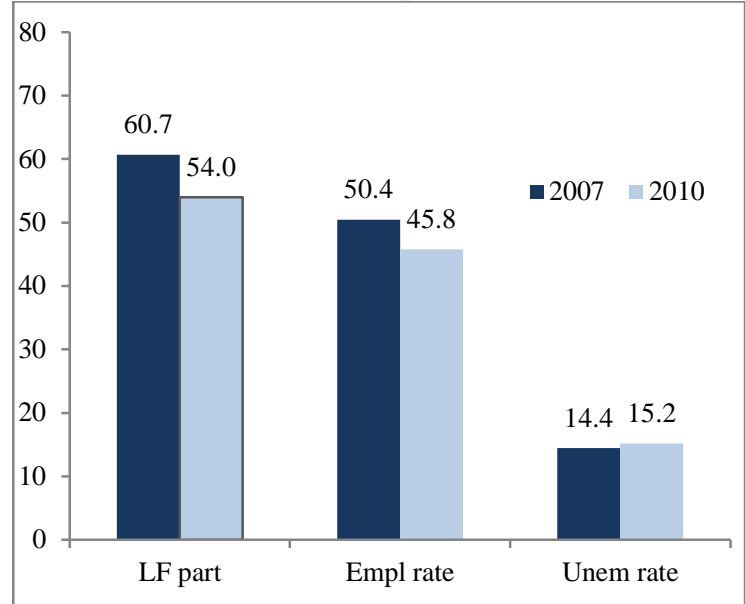

1b. Ages 25 - 34 (in percent)

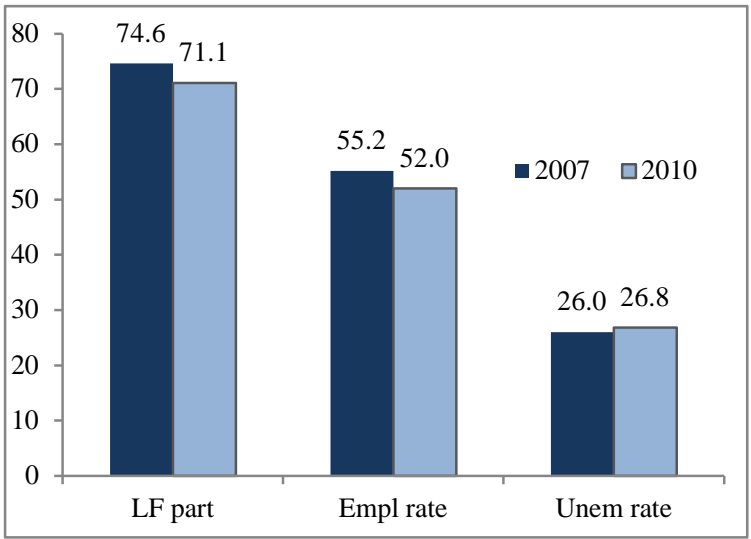

1d. All ages, 15 years + (in percent)

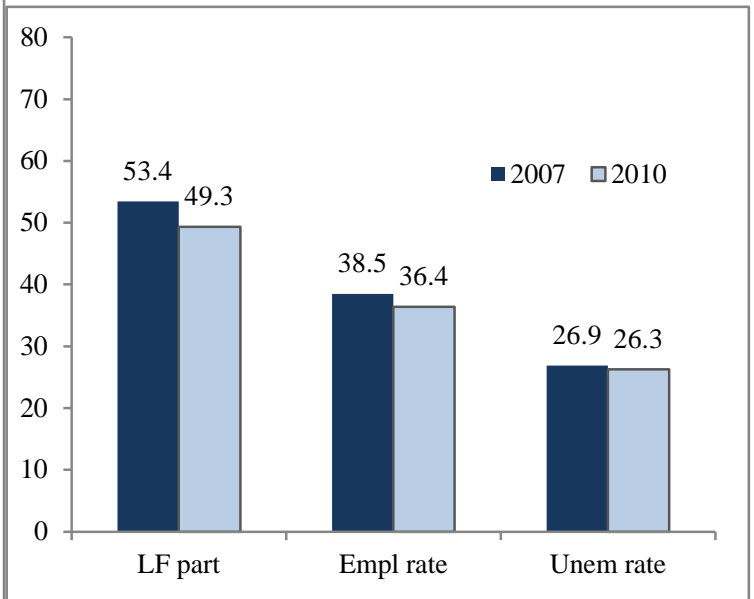

1e. Labor force participation (\% of population) 1f. Unemployment (2010, \% of labor force)
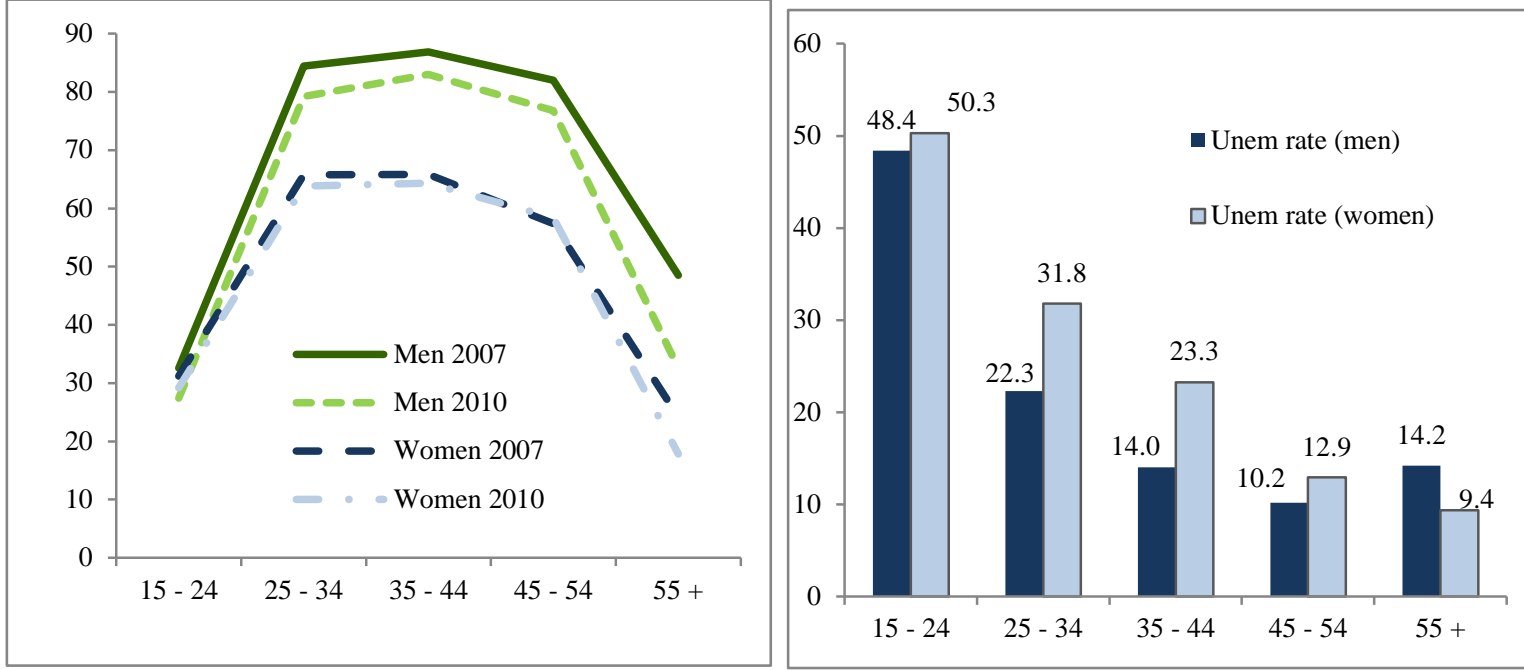

Source: Authors' calculations based on the 2007 and 2010 Swaziland Integrated Labor Force Surveys. 1/ The youth is defined as population aged 15 - 24 years, while adult population are people aged 25 years and above. 
Table 2. Swaziland: Labor force participation, employment and unemployment, by gender

\begin{tabular}{lcccccc}
\hline & \multicolumn{2}{c}{ Total } & \multicolumn{2}{c}{ Men } & \multicolumn{2}{c}{ Women } \\
& 2007 & 2010 & 2007 & 2010 & 2007 & 2010 \\
\hline Unemployment (\% of LF) & 26.8 & 26.3 & 24.0 & 22.7 & 30.3 & 30.0 \\
Employment (\% of pop.) & 39.0 & 36.4 & 46.4 & 42.4 & 32.3 & 31.2 \\
Labor Force Participation (\% of pop.) & 53.4 & 49.3 & 61.0 & 54.8 & 46.6 & 44.6 \\
\hline
\end{tabular}

Source: Authors' calculations based on the 2007 and 2010 SLFS.

Data divided by age groups reveal that the gender unemployment gap is most pronounced among the 25 -- 44 year group, with the unemployment rates of women being almost one third higher than the rate of men. ${ }^{9}$ As in other African countries, women's labor force participation is below that of men across most age categories (Figures 1e and 1f).

\section{(2) The less educated}

Unemployment has been disproportionally concentrated among the less educated segments of the population (e.g., people with primary or no education). While in 2007 unemployment rate for people with tertiary education was 8.1 percent, it reached 32.5 percent for those with primary education or less. Having some secondary education is critical - people with primary education or less accounted for more than half of the unemployed among youth and about half among adults (Figure 2). Moreover, the high unemployment rate for high school graduates points to a steep return to tertiary education.

Figure 2. Swaziland: Unemployment by Education, Youth and Adults (2007)

2a. Unemployment by education, youth

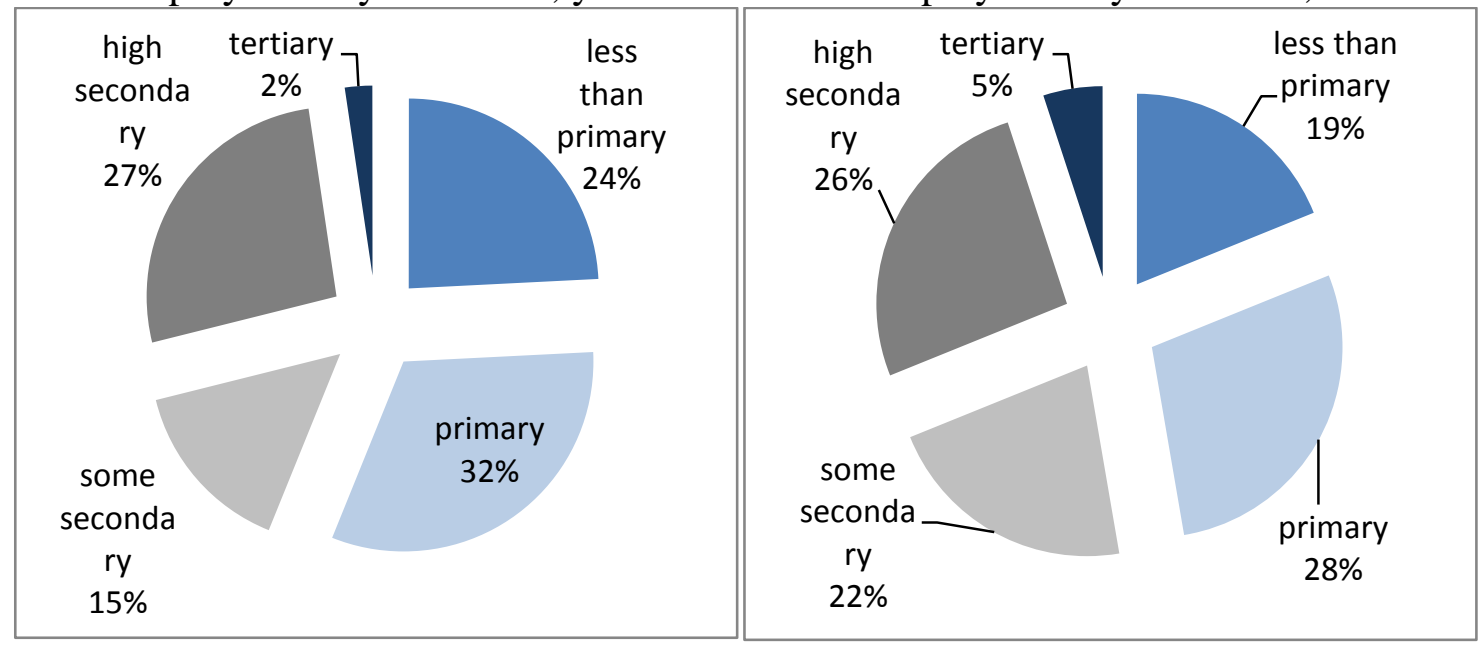

Source: Authors’ calculations based on the 2007 Swaziland Labor Force Survey.

(3) Youth

At 52.7 percent of the labor force in 2007, youth unemployment was alarmingly high and among the highest in Africa, including in the SACU countries (Figure 3). The labor market situation deteriorated

\footnotetext{
${ }^{9}$ At the same time, unemployment rate for women over 55 years is lower than for their male counterparts, even though women's labor force participation gap this age group is smaller than for the younger cohorts.
} 
further between 2007 and 2010: while the official unemployment slightly declined (to 49.4 percent), both employment rate and the labor force participations of youth also dropped (Figure 1a). In fact, if the youth labor force participation remained at the 2007 level, the 2010 youth unemployment rate would amount to 55.1 percent of the labor force. Further, if all discouraged young people were in the labor force and searching, the youth unemployment would exceed 60 percent in both 2007 and 2010.

In 2010, youth accounted for 37.7 percent of all unemployed, while people aged 25 - 34 years constituted another 37 percent. The bulk of unemployed was among the youth aged $20-24$ years, constituting more than 30 percent of all unemployed. Of concern is also the declining employment rate in this age group during 2007 and 2010. With these rates and trends, youth unemployment ceases to be an economic issue only. As the 2011 experiences from North Africa showed, if unaddressed, the low and declining youth employment could lead to social and political unrests.

Figure 3. Youth and Adult Unemployment Rates in Selected African Countries

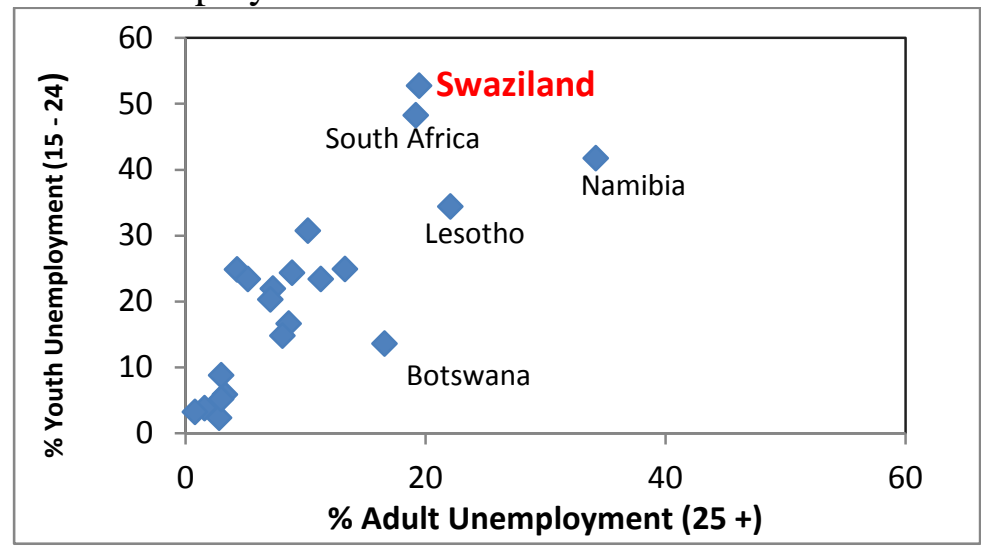

Source: Based on SLFS (2007) and AfDB et al. (2012). Note: Countries other than Swaziland were included based on data availability in the ILO KILM, 7th Edition. The unemployment rates are in \% of the labor force.

\section{b. Understanding youth labor market disadvantages}

The sections below document the labor market disadvantages faced by Swazi youth. A range of indicators highlight the type of disadvantages and more vulnerable youth sub-groups.

Unlike in Africa's low income countries where most young people belong to "working poor", unemployment is an important challenge in Swaziland. In 2007 and 2010 surveys, about half of the labor force aged 15 - 24 were unemployed, while the youth/adult unemployment ratio in the country was 2.7 and 2.4 n 2007 and 2010, respectively. Despite Swaziland's small size, substantial differences in these ratios existed among regions and administrative areas. Nevertheless, unemployment rate was higher for youth than for the adults in all but two administrative areas (Figure 4).

Unemployment impacted youth disproportionally in the urban areas, where the youth unemployment rate was more than triple the adult rate (Table 3 and Table I, Annex I). The unemployed urban youth accounted for 45 percent of unemployed, with almost one out of five young people being unemployed. 
Figure 4. Swaziland: Unemployment, by Inkhundla, (2007, \% of labor force)

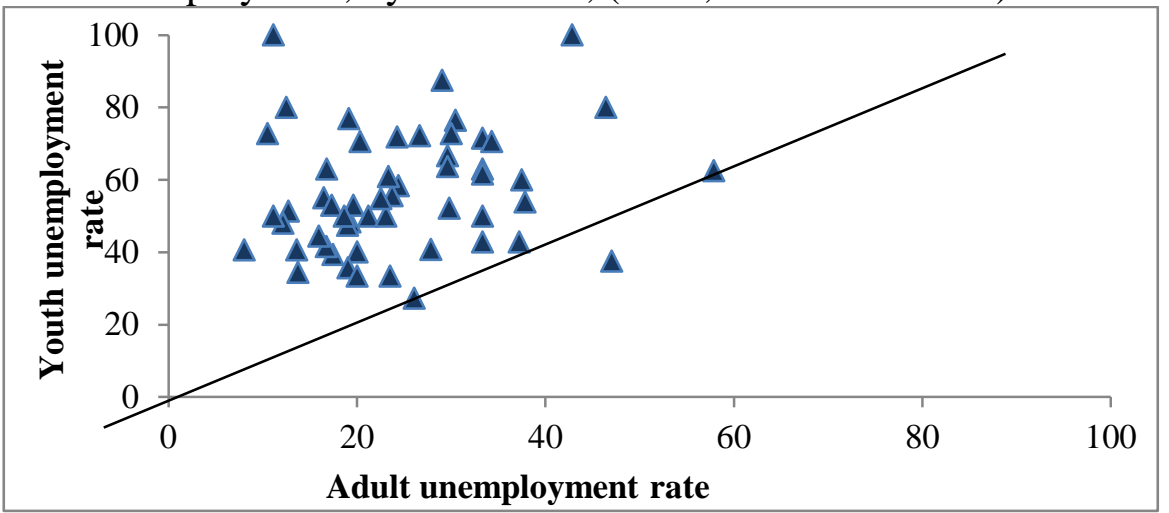

Source: Authors' calculations based on the 2007 and 2010 SLFS. Note: Inkhundla is an administrative area. Given the small sample size per area, these figures are indicative, but reflect the overall trend.

Table 3. Swaziland: Youth Unemployment, 2007 and 2010

\begin{tabular}{lccccc}
\hline $\mathbf{2 0 0 7}$ & All & \multicolumn{2}{c}{ By gender } & \multicolumn{2}{c}{ By area } \\
& & Male & Female & Urban & Rural \\
\hline Youth Unemployment Rate (\% of LF) & 52.7 & 50.3 & 55.2 & 46.7 & 58 \\
Adult Unemployment Rate ( \% of LF) & 19.5 & 17.4 & 22.1 & 14.3 & 32 \\
Ratio of Youth to Adult Unempl. Rate & 2.7 & 2.9 & 2.5 & 3.3 & 1.8 \\
Youth Unemployment Ratio (\% of pop.) & 16.8 & 16.3 & 17.2 & 18.9 & 15.6 \\
Youth LF Participation Rate (\% of pop.) & 31.9 & 32.6 & 31.2 & 40.4 & 26.9 \\
\hline $\mathbf{2 0 1 0}$ & All & \multicolumn{2}{c}{ By gender } & \multicolumn{2}{c}{ By area } \\
& \multicolumn{7}{c}{ Male } & Female & Urban & Rural \\
\hline Youth Unemployment Rate (\% of LF) & 49.5 & 48.4 & 50.3 & 35.5 & 61.7 \\
Adult Unemployment Rate ( \% of LF) & 20.0 & 16.9 & 23.5 & 12.3 & 29.6 \\
Ratio of Youth to Adult Unempl. Rate & 2.5 & 2.9 & 2.1 & 2.9 & 2.1 \\
Youth Unemployment Ratio (\% of pop.) & 14.0 & 13.3 & 14.7 & 13.4 & 14.3 \\
Youth LF Participation Rate (\% of pop.) & 28.4 & 27.4 & 29.2 & 35.5 & 23.2 \\
\hline
\end{tabular}

Source: Authors' calculations based on 2007 and 2010 Labor Force Surveys. Note: Young people are defined as ages 15 24 , adults as ages $25+$.

Youth with tertiary education are almost seven times more likely to be unemployed than their adult counterparts. The notably higher unemployment rates for youth than for adults point to mismatches between the skills of the graduates and those demanded by the market, raising questions about relevance of tertiary education (Marope, 2010). ${ }^{10}$

\section{(ii) Youth disadvantage as discouragement}

Long unemployment spells prevail among youth almost as much as among adults. In 2007, three quarters of young unemployed Swazis were available for employment for over one year (Swaziland Ministry of Labor, 2008). Because of the long job search, significant shares of young people, especially

\footnotetext{
${ }^{10}$ In Tunisia and other North African countries, the unemployment pool contained a disproportionate share of the educated youth (Stampini and Verdier-Chouchane, 2011).
} 
women and the rural population, have been discouraged from job search. Hence while open youth unemployment is a key challenge in the urban areas, discouragement is widespread in rural settings. Moreover, the gap between 'relaxed' youth unemployment rates in the rural and urban areas markedly widened from about 14 percentage points of the labor force in 2007 to 25 percentage points in 2010 (Table 4).

Extended periods of idleness can lead to 'scarring', that is the impairment of employment and income prospects through low wages, underemployment, and low-pay-no-pay cycles as well as the loss of human capital. Social exclusion is another negative consequence of youth idleness. The young people miss out on critical life-skill building experiences such as applying their knowledge, developing a sense of own abilities and contributing meaningfully to society (Scarpetta et al., 2010; Khumalo, 2011).

Table 4. Swaziland: Youth Discouragement, 2007 and 2010

\begin{tabular}{|c|c|c|c|c|c|}
\hline & \multirow[b]{2}{*}{ Total } & \multicolumn{2}{|c|}{ Gender } & \multicolumn{2}{|c|}{ Area } \\
\hline & & Male & Female & Urban & Rural \\
\hline \multicolumn{6}{|c|}{2007 Relaxed' unemployment rate (\% of modified LF) } \\
\hline Total $(15+)$ & 36.6 & 30.8 & 42.7 & 27.5 & 45.3 \\
\hline Youth $(15-24)$ & 63.2 & 59.2 & 66.8 & 55.7 & 69.2 \\
\hline Teenagers (15 - 19) & 67.4 & 64.0 & 70.1 & 66.7 & 67.8 \\
\hline Young Adults (20 - 24) & 61.7 & 57.5 & 65.4 & 52.3 & 69.7 \\
\hline Adults $(25+)$ & 27.9 & 22.7 & 33.7 & 19.4 & 36.5 \\
\hline \multicolumn{6}{|c|}{2010 Relaxed' unemployment rate (\% of modified LF) } \\
\hline Total $(15+)$ & 37.0 & 30.2 & 43.6 & 22.8 & 51.0 \\
\hline Youth (15 - 24) & 61.0 & 57.6 & 63.6 & 45.6 & 72.5 \\
\hline Teenagers (15 - 19) & 66.3 & 64.5 & 67.6 & 51.0 & 75.6 \\
\hline Young Adults (20 - 24) & 59.7 & 55.9 & 62.6 & 44.4 & 71.6 \\
\hline Adults $(25+)$ & 30.4 & 23.6 & 37.3 & 17.5 & 44.0 \\
\hline
\end{tabular}

Source: Authors calculations based on the 2007 and 2010 SLFS. Note: 'relaxed' definition of unemployment captures discouraged workers, both in the unemployment pool and in the labor force.

\section{(iii) Youth disadvantage as holding jobs of lower quality}

The quality of employment - in terms of job security and wages - is another dimension where the Swazi youth are disadvantaged relative to adults. As common elsewhere, on average young people in Swaziland also hold less secure jobs than adults. The lack of employment with contracts among youth implies that youth are not protected by the labor code and/or against health risk and the old age (Kolev and Saget, 2005). While more than half of the employed adults are covered by social security, less than one third of youth has such coverage (Figure 5).

Young people are less likely than adults to work in high paying segments of the economy such as public sector or business services. In 2007, only 5 percent of youth were employed in the public sector in contrast to 24 percent of adults (Table 5). Within the private sector, young people were employed more in the less paying fields such as retail trade or agriculture. This, combined with their experience, resulted in much lower incomes than those earned by adults. Specifically, only $9.2 \%$ of youth have monthly salary above 1,500 emalangeni (about 150 euros) relative to 485 of adults, pointing to a high prevalence of working poverty among youth, as in other countries (Guarcello et al., 2012). 
Figure 5. Swaziland: Quality and Security of Employment, 2007, (\% of employed)

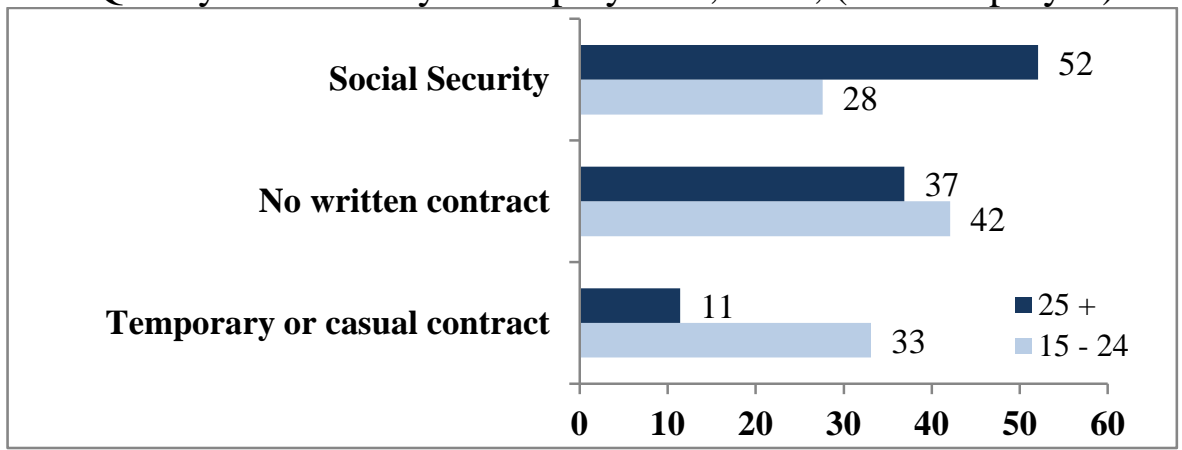

Source: Authors' calculations based on the 2007 SLFS.

Table 5. Sectoral distribution of employment, by age and gender

\begin{tabular}{lcccccc}
\hline & \multicolumn{3}{c}{ Youth } & \multicolumn{3}{c}{ Adults } \\
& Total & Men & Women & Total & Men & Women \\
\hline & (\% of total employment in each category) & & \\
Public Sector & 5.1 & 5.7 & 4.4 & 23.9 & 23.2 & 24.9 \\
Private Sector, formal & 76.3 & 79.8 & 72.7 & 56.9 & 64.9 & 46.2 \\
Private Sector, informal & 13.8 & 9.5 & 18.2 & 17.3 & 11.1 & 25.4 \\
Domestic workers & 4.9 & 5.0 & 4.7 & 2.0 & 0.8 & 3.5 \\
\hline
\end{tabular}

Source: Authors' calculations based on the 2007 SLFS. Note: Dependency ratio is people below 15 and above 64 years old relative to the working age population $(15-64)$.

\section{Determinants of Youth Unemployment}

This section discusses both supply-side (e.g., demographic, social) and demand-side (e.g., private sector growth) drivers of youth unemployment, with a view to inform policies.

\section{a. Supply-side factors}

\section{(i) Demographic trends}

In 2010, young people amounted to 43 percent of Swaziland working age population (Figure 6a). The share of youth in the population aged 15 years or above was higher not only than the average in Southern Africa, but also than in sub-Saharan Africa (SSA) and among the least developed countries world-wide.

Due to the ongoing demographic transition the dependency ratio is projected to decline rapidly, presenting a potential demographic dividend (Figure 6b). Swaziland will reap this dividend only if its workers, including youth, have productive jobs. So far, a large portion of the country's working age population, and especially youth, has been underutilized. 
Figure 6a. Share of youth in working age population (15+), 1950 - 2030 (\%)

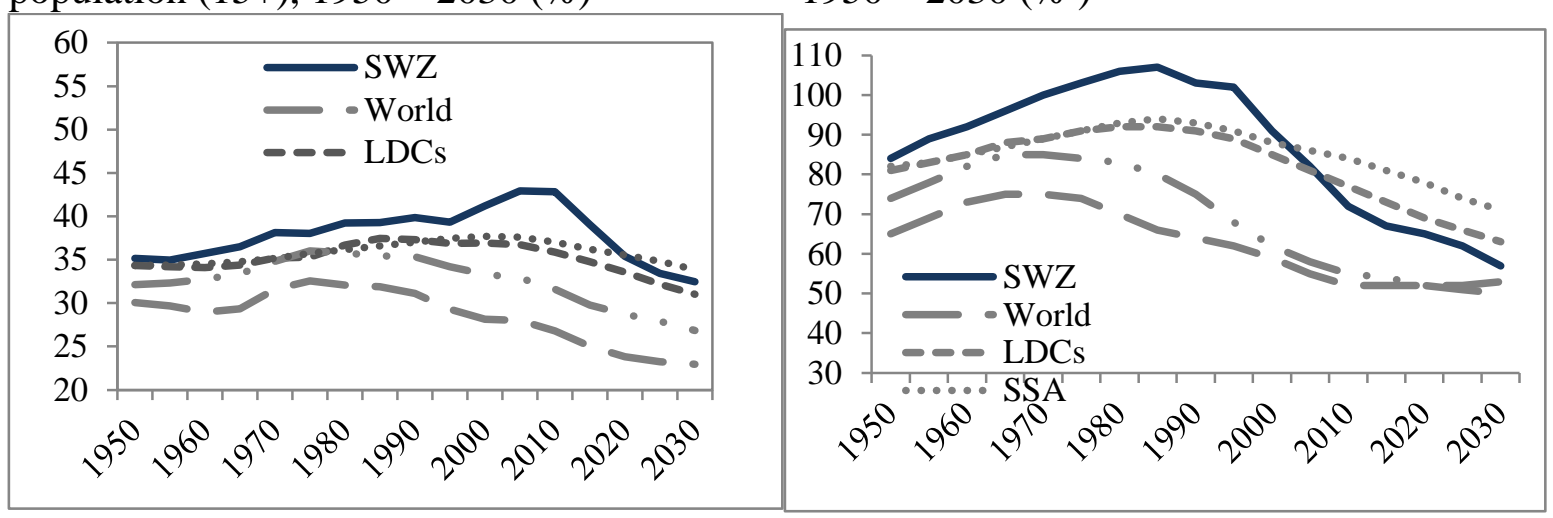

Source: Authors' calculations based on data from the UN Population Division.

\section{(ii) Socio-economic determinants of youth unemployment}

This Section examines some of the key socio-economic factors (e.g., age, gender, education) contributing to high youth unemployment. We study young adults (ages 20 - 29) since tertiary education and self-employment are relatively rare among teenagers (ages 15 - 19).

\section{Methodology}

Utilizing a multinomial logit model, the identification strategy can be written as follows:

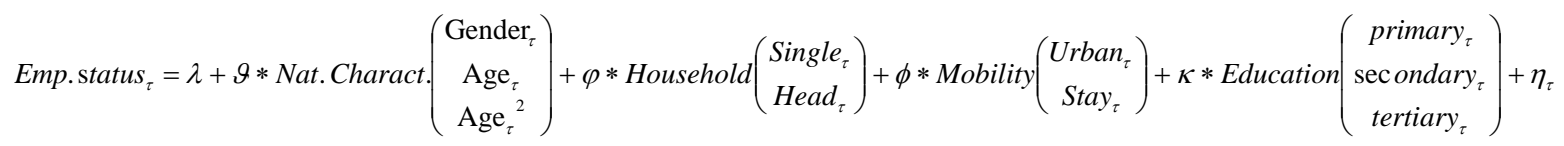

where $\tau$ stands for individuals; Emp. status is the outcome categorical variable indicating whether the individual has a wage employment in the public sector, the formal private sector, the informal private sector, or is self-employed, inactive or unemployed. The vector of controls includes demographic characteristics such as gender and age, household-related characteristics such as the marital status and the individual's responsibility in the household, proxies of mobility such as the geographical location (urban versus rural) and the length of stay in the area, and education variables.

The gender variable (dummy taking the value 1 for women and 0 for men) captures any gender gap in the labor market. Age and $A g e^{2}$ test the sensitivity of the likelihood of the employment status depend on age. Marital status (proxied by a dummy variable - Single - taking the value of 1 the individual is single and 0 otherwise) and responsibility in the household (proxied by a dummy variable - Head - taking the value of 1 if the individual is a head of household and 0 otherwise) take into account the fact that household head and married people may have higher incentives work so as to secure an adequate income stream for the household. As people living in urban areas may have higher job opportunities in the formal private and public sectors, we include a dummy variable (Urban) taking the value of 1 if the individual lives in an urban area and 0 otherwise. Mobility (proxied by Stay, a dummy variable taking the value of 1 if the individual has been living in the area since birth and 0 otherwise) accounts for knowledge and network effects related to the duration of stay in the area. Lastly, we include as 
regressors a set of education dummy variables (primary, secondary, tertiary) taking the value of 1 if the individual has achieved a primary, secondary and tertiary education, respectively.

Unemployment is the reference state. The other states are employment in the public sector, the formal private sector, the informal private sector, inactivity, and self-employment. For each state, the estimated coefficients represent the likelihood of being in that state rather than in unemployment, given each independent variable such as age, gender, education, area and mobility. Results are in Table $6 .{ }^{11}$

\section{Results}

Education, both secondary and tertiary, raised young adults' chances of working in the public sector relative to being unemployed in both 2007 and 2010. Tertiary education also reduced the likelihood of being inactive. Taken together with a small tertiary graduates in the country, the implications point to the need for an increase access. At the same time, the quality of education cannot be compromised. Recently evidence of skill mismatches has emerged, with the young educated job seekers not having skills demanded by employers' (e.g., business, technical, ICT skills). This could be addressed through reforming the educational curricula and more efficient matching of graduates with vacancies.

Age also improved chances of young adults having a formal wage employment, being inactive or selfemployed in 2010. Specifically, a higher age in the range 20-29 was associated with higher probability of being employed in the formal private sector or being self-employed, confirming that young people have difficulties finding jobs in the public sector. Since Age squared had a negative and significant coefficient for the formal private and self-employment status, there may be a turning point in the impact of age on the likelihood of working in the formal private sector or as self-employed. This suggests that after gaining experience in the private sector, young people are able to switch to the public sector which offers higher wages.

Gender also played a role in the 2007 and 2010 labor market outcomes of young adults. Women were less likely to be employed in the formal public and private sector than unemployed. In contrast, they were more likely to be inactive and self-employed.

Young adults in urban areas had higher chances to work in the formal private sector (both in 2007 and 2010) or to be self-employed (in 2007) than rural youth. At the same time, urban location likelihood of being inactive rather than unemployed. In 2007, young urban residents were also less likely to work in the formal public sector rather than unemployed.

Higher mobility (measured as whether an individual has lived in the area since birth or not) raised young adults' chances of being employed in the public and private (formal and informal) sector rather than being unemployed in both 2007 and 2010. This is expected, since mobility is often linked with greater dynamism and desire to gain training and experience).

\footnotetext{
11 One question in our regression model is whether the controls may be collinear, i.e. if there may be statistical dependencies among them. To address this concern, we use of variance inflation factor to identify multicollinearity, as in Wooldridge (2000). The results in the last column of Table 6 indicate that except for Age and Age ${ }^{2}$, all controls have VIF lower than 10, implying that multi-collinearity is not an issue in our regression analysis. The high collinearity of the Age variables was expected and is not a source of biased inference.
} 
Table 6. Multinomial Logit Regressions, Ages 20 - 29

\begin{tabular}{|c|c|c|c|c|c|c|}
\hline 2007 & Public & $\begin{array}{c}\text { Private } \\
\text { (formal) }\end{array}$ & $\begin{array}{c}\text { Private } \\
\text { (informal) }\end{array}$ & Inactive & Self-employed & $V I F *$ \\
\hline \multicolumn{7}{|l|}{ Demographic characteristics } \\
\hline Gender $(1=$ female $)$ & $-.17(.21)$ & $-.15(.12)$ & $.52(.51)$ & $.01(.57)$ & $.19(.19)$ & 1.13 \\
\hline Age & $.56(.96)$ & $.21(.42)$ & $.97(1.67)$ & $.94(1.72)$ & $-.01(.65)$ & 364.88 \\
\hline Age squared & $-.006(.019)$ & $-.002(.008)$ & $-.02(.03)$ & $-.02(.04)$ & $.003(.01)$ & 364.67 \\
\hline \multicolumn{7}{|l|}{ Household-related characteristics } \\
\hline Single & $-.06(.24)$ & $-.09(.14)$ & $.74(.78)$ & $-1.13^{(\mathrm{a})}(.45)$ & $-1.13^{(a)}(.20)$ & 1.17 \\
\hline Head & $1.54^{(\mathrm{a})}(.27)$ & $1.57^{(\mathrm{a})}(.17)$ & $.33(.82)$ & $1.66^{(\mathrm{a})}(.69)$ & $1.81^{(\mathrm{a})}(.25)$ & 1.32 \\
\hline \multicolumn{7}{|l|}{ Mobility and location } \\
\hline Urban & $-.56^{(\mathrm{a})}(.22)$ & $.26^{(\mathrm{b})}(.13)$ & $-1.06(.66)$ & $-1.72^{(\mathrm{a})}(.72)$ & $-.20(.20)$ & 1.4 \\
\hline Lenght of stay & $-.49^{(\mathrm{b})}(.24)$ & $-.68^{(\mathrm{a})}(.14)$ & $-1.64^{(\mathrm{a})}{ }_{(.67)}$ & $-.11(.76)$ & $-.22(.21)$ & 1.52 \\
\hline \multicolumn{7}{|l|}{ Level of education } \\
\hline Primary & $-.06(.52)$ & $-.06(.19)$ & $.69(.77)$ & $19.6(20.6)$ & $.17(.33)$ & 6.48 \\
\hline Secondary & $1.06^{(\mathrm{a})}(.45)$ & $-.15(.18)$ & $-.27(.77)$ & $19.28(20.65)$ & $.32(.32)$ & 6.72 \\
\hline Tertiary & $2.84^{(\mathrm{a})}(.49)$ & $.19(.28)$ & $43.33^{-(a)}(.68)$ & $19.76(.61)$ & $.57(.44)$ & 2.81 \\
\hline Intercept & $-12.67(13.31)$ & $-3.9(5.11)$ & $-15.69_{(20.76)}$ & $-32.1(-)$ & $-3.08(8.02)$ & - \\
\hline Pseudo $R^{2}$ & 0.13 & 0.13 & 0.13 & 0.13 & 0.13 & - \\
\hline Obs & 1781 & 1781 & 1781 & 1781 & 1781 & - \\
\hline
\end{tabular}

2010

\section{Demographic characteristics}

\begin{tabular}{|c|c|c|c|c|c|c|}
\hline Gender $(1=$ female $)$ & $-.34_{(.21)}^{(\mathrm{c})}$ & $-.44^{(a)}(.14)$ & $.22(.17)$ & $.51_{(.15)}^{(\mathrm{a})}$ & $.42^{(\mathrm{b})}(.21)$ & 1.12 \\
\hline Age & $1.34(.86)$ & $.94^{(\mathrm{b})}(.47)$ & $.05(.6)$ & $-.97^{(\mathrm{b})}(.48)$ & $1.43^{(b)}(.75)$ & 379.13 \\
\hline Age squared & $-.02(.02)$ & $-.02^{(b)}(.009)$ & $-.0004(.02)$ & $.02^{(\mathrm{b})}(.01)$ & $-.03^{(\mathrm{c})}(.02)$ & 379.27 \\
\hline \multicolumn{7}{|c|}{ Household-related characteristics } \\
\hline Single & $-.45^{(\mathrm{b})}(.23)$ & $-.095(.16)$ & $.46^{(\mathrm{b})}(.23)$ & $-.51_{(\mathrm{a})}^{(.16)}$ & $-.76^{(\mathrm{a})}(.21)$ & 1.21 \\
\hline Head & $1.92^{(\mathrm{a})}(.24)$ & $1.24_{(.18)}^{(\mathrm{a})}$ & $1.01_{(.22)}^{(\mathrm{a})}$ & $.39^{(\mathrm{c})}(.24)$ & $1.70_{(.24)}^{(\mathrm{a})}$ & 1.29 \\
\hline \multicolumn{7}{|l|}{ Mobility and location } \\
\hline Urban & $.24(.21)$ & $1.04_{(.14)}^{(a)}$ & $.79^{(\mathrm{a})}(.19)$ & $-.27_{(.16)}^{(\mathrm{c})}$ & $.76^{(\mathrm{a})}(.21)$ & 1.34 \\
\hline Lenght of stay & $-.41^{(\mathrm{c})}(.23)$ & $-.84_{(.15)}^{(a)}$ & $-.54_{(.2)}^{(\mathrm{a})}$ & $-.16(.18)$ & $-.07(.22)$ & 1.46 \\
\hline \multicolumn{7}{|l|}{ Level of education } \\
\hline Primary & $-.37(.48)$ & $-.3(.19)$ & $-.2(.23)$ & $-.23(.2)$ & $-.42(.29)$ & 1.81 \\
\hline Secondary & $.82^{(\mathrm{b})}(.41)$ & $-.28(.18)$ & $-.85^{(a)}(.23)$ & $-.39^{(\mathrm{b})}(.19)$ & $-.61(.28)$ & 1.93 \\
\hline Tertiary & $2.98^{(\mathrm{a})}(.46)$ & $.38(.3)$ & $-1.05^{(\mathrm{b})}(.5)$ & $-.25(.4)$ & $-.57(.49)$ & 1.39 \\
\hline Intercept & $-20.95^{(\mathrm{b})}(11)$ & $-12.99(5.77)$ & $-2.33(7.38)$ & $11.92^{(\mathrm{b})}(5.8)$ & $-20.6^{(\mathrm{a})}(9.24)$ & - \\
\hline Pseudo $R^{2}$ & 0.13 & 0.13 & 0.13 & 0.13 & 0.13 & - \\
\hline Obs & 2013 & 2013 & 2013 & 2013 & 2013 & - \\
\hline
\end{tabular}

Notes: $\overline{\overline{\text { Robust standard errors are in parentheses. }{ }^{(\mathrm{a})} \text { denotes significance at } 1 \%,{ }^{(\mathrm{b})} \text { at } 5 \% \text { and }{ }^{(\mathrm{c})} \text { at } 10 \% .}{ }^{*} \text { VIF: Variance }}$ Inflation Factor values. 
In sum, higher education, living in urban areas and being mobile increased employment chances of young people. Among young adults, women and very young people had lower probability of employment in the private sector relative to being unemployed, reiterating the need to pay special attention to these groups.

\section{b. Demand-side factors}

With Swaziland's persistently low growth the main constraints to decent job creation reside mostly on the demand side of the labor market, even though supply side factors undoubtedly matter as well for youth employment outcomes. Due to weak business environment, private investment (as share of GDP) has been low even in comparison to other countries in the region (Table 7). It has received another setback in recent years with the deteriorating fiscal situation which has hampered both FDI inflows and SME activities (UN Swaziland, 2012).

Table 7. The Size of the Private Sector: Swaziland and Other SACU Countries

\begin{tabular}{lcc}
\hline & $\begin{array}{c}\text { Private investment } \\
1990-2011\end{array}$ & $\begin{array}{c}\text { Private Sector Credit } \\
\text { 2000-2011 }\end{array}$ \\
\hline Botswana & 15.3 & (\% of GDP) \\
Swaziland & $\mathbf{9 . 9}$ & 19.8 \\
South Africa & 13.0 & $\mathbf{1 9 . 2}$ \\
Namibia & 14.4 & 139.3 \\
Lesotho & 32.4 & 46.4 \\
\hline
\end{tabular}

Source: Authors' calculations based on the data from the WDI database.

In 2013 Swaziland ranked \#123 out of 185 countries on the Doing Business (World Bank, 2013). The country scored low in the 'Starting a Business' category (\#165/185 countries), reflecting high start-up cost and lengthy procedures. The 'Enforcing Contracts' category (\#174/185) also left room for significant improvement, especially in cutting number of days and procedures required. Relatively low rankings on 'Registering Property' (\#129/185) and 'Protecting Investors' (128/185) also impede investment and SME start-ups, alongside trade barriers. Overall, in the past five years, Swaziland has shown only limited improvement in most reform categories measured by Doing Business reforms.

In Africa the lack of structural transformation from low to high productive jobs is a key impediment to decent employment, including among youth (Page, 2012). This applies also to Swaziland. While the economy is diversified relative to other SSA countries, low value added activities (e.g., subsistence agriculture, trade) predominate in employment. In recent years, the oversized public sector kept hires at a minimum while the stagnating private sector could not absorb new labor force entrants.

With high unemployment, questions arise to what extent labor market institutions have been driving this outcome. Even though these institutions are not particularly flexible in Swaziland when compared to small, fast growing economies, they fare well relative to other SACU countries (Table 8). Moreover, they are not a main obstacle to job creation, since they are usually enforced only partially. 
Table 8. Labor Market Flexibility 1/

\begin{tabular}{|c|c|c|c|c|c|c|}
\hline & $\begin{array}{c}\text { Pay relative } \\
\text { to } \\
\text { Productivity }\end{array}$ & $\begin{array}{l}\text { Flexibility of } \\
\text { wage } \\
\text { determination }\end{array}$ & $\begin{array}{l}\text { Labor - } \\
\text { employer } \\
\text { relations }\end{array}$ & $\begin{array}{l}\text { Hiring and } \\
\text { Firing } \\
\text { Practices }\end{array}$ & $\begin{array}{c}\text { Redundancy } \\
\text { Cost } \\
\text { (weeks) }\end{array}$ & $\begin{array}{c}\text { Professional } \\
\text { Management }\end{array}$ \\
\hline & \multicolumn{6}{|c|}{ Ranking (index), unless otherwise indicated } \\
\hline Swaziland & $132(3.0)$ & $106(4.4)$ & $85(4.1)$ & $111(3.3)$ & 8.7 & $74(4.2)$ \\
\hline Global average & 3.9 & 4.9 & 4.4 & 3.9 & 11.8 & 4.3 \\
\hline SSA median & 3.3 & 4.9 & 4.1 & 3.9 & 9.1 & 4.0 \\
\hline \multicolumn{7}{|c|}{ Fast growing small economies } \\
\hline Estonia & $7(5.1)$ & $6(6.0)$ & $34(4.8)$ & $28(4.5)$ & 4.3 & $25(5.2)$ \\
\hline Mauritius & $74(3.8)$ & $107(4.4)$ & $43(4.7)$ & $82(3.8)$ & 6.3 & $60(4.4)$ \\
\hline Rwanda & $46(4.2)$ & $38(5.5)$ & $30(4.9)$ & $43(4.3)$ & 8.7 & $37(4.9)$ \\
\hline Singapore & $1(5.5)$ & $7(6.0)$ & $2(6.1)$ & $2(5.8)$ & 0.0 & $11(5.9)$ \\
\hline
\end{tabular}

Source: GCR 2011/2012. 1/Index scale is $1-7$, with higher values indicating greater flexibility. Note: Pay relative to productivity - whether pay reflects productivity; flexibility of wage determination - wages are set (1) by centralized bargaining or (7) by individual companies; labor - employer relations are (1) confrontational or (7) cooperative; hiring and firing practices are (1) impeded by regulations or (7) flexibly determined; professional management -- senior management positions are determined by (1) merit or (7) connections.

\section{Policies Towards Youth Employment in Swaziland}

Tackling youth employment is a complex challenge that extends beyond labor market interventions and includes addressing macroeconomic management and performance; the infrastructure gap, low productivity; unclear regulations, including land ownership; and often political setting with leadership that prioritizes the issue (JICA, World Bank and African Development Bank, 2013). The interventions discussed below focus on labor market policies or related measures, leaving the other important aspects to further research.

\section{a. Policies towards creating jobs for youth}

The evidence of youth skills shortages and mismatches among young people with tertiary education has emerged. The educated youth often do not have the skills demanded by employers and/or are not aware where to find suitable jobs. Reforms of tertiary education, expansion of vocational and on-the-job training could over time address these shortages, while labor exchanges could reduce mismatches.

Some issues need to be also tackled on the supply side of the labor market. Currently, with the public sector offering the best paid and most secure jobs, many recent graduates "get in line" for jobs in the public sector. Experience in the public sector is also viewed as entry into even better paid private industries, such as banking. To change relative attractiveness of the public sector and majority of private sector jobs, some regulation of the public wage bargaining process may be needed.

With the stagnant public sector, the key bottleneck to youth employment has been an insufficient creation of productive jobs in the private sector. A vibrant private sector that would provide high paying and productive jobs (as is already the case in the banking sector, for example) is the key to a lasting reduction in youth unemployment. The role of an enabling regulatory framework thus cannot be emphasized enough. The government has recognized the need to improve business environment and in the early 2012 re-launched Investor Road Map in an effort to cut red tape and attract investment. 
Besides fundamentals such as macroeconomic stability, business environment, human capital, and the rule of law (Anyanwu, 2013 and World Bank, 2013c), sectoral polices can stimulate youth employment. The ICT industry, which currently lags behind other SSA countries, could generate jobs for youth. With their ability to adapt to changes and innovate, young people could drive techentrepreneurship (Lisk and Dixon-Fyle, 2013). For example, the implementation of the e-government strategy could create new job opportunities for youth that would unlock their creative potential. Youth are also well-positioned to lead development of innovative e- and m-services in initiatives such as ewallet, e-health or m-banking (AfDB et al, 2012). The barriers to entering the ICT sectors impact youth more though, due to their greater aptitude for innovation, and should be eased (Table 9).

ICT can also improve labor market outcomes indirectly, by raising productivity. Swaziland has recently taken steps to increase productivity in agriculture through training young farmers and rural entrepreneurs in ICT. Still ICT is not an employment intensive sector and other sectors, such as manufacturing, productive services and tourism will need to be the backbone of employment. Given that many young people work in the informal sector, the government may like to remove constraints on raising the sector's productivity, as suggested also for other African countries (JICA et al., 2013).

Recently entrepreneurship has gained increased attention of Swazi policymakers as a venue to tackle the youth employment challenge. This attention rests on two main factors. First, in Swaziland, where the public sector is oversized and the external demand dampened by subdues growth of South Africa, stimulating domestic private sector through entrepreneurship provides a viable alternative. Second, besides building livelihoods, entrepreneurship can help young people develop their identity and integrate into the society by offering a sense of 'meaning' and 'belonging'. These benefits have become increasingly important with weakening family and community structures (White and Kenyon, 2000).

Table 9. Swaziland: key actual \& considered policy instruments towards youth employment

\begin{tabular}{|c|c|c|c|}
\hline $\begin{array}{l}\text { 1. Moving youth closer to } \\
\text { jobs (supply side) }\end{array}$ & $\begin{array}{l}\text { Implementation } \\
\text { Status }\end{array}$ & $\begin{array}{l}\text { 2. Generating jobs for youth } \\
\text { (demand side) }\end{array}$ & $\begin{array}{l}\text { Implementation } \\
\text { Status }\end{array}$ \\
\hline $\begin{array}{l}\text { a. Impacting expectations } \\
\text { - Contain wage in the public } \\
\text { sector } \\
\text { - Limit size of the public sector } \\
\text { - Develop the private sector } \\
\text { b. Affecting quality of labor } \\
\text { - Reform educational system } \\
\text { - Expand vocational training }\end{array}$ & $\begin{array}{l}\text { partly } \\
\text { partly } \\
\text { partly }\end{array}$ & $\begin{array}{l}\text { a. Improve business environment } \\
\text { - especially in strategic sectors (ICT) } \\
\text { - improve access to credit } \\
\text { b. Support youth entrepreneurship } \\
\text { - with training and funding } \\
\text { c. Make youth employment attractive } \\
\text { - Provide subsidies to wages of young } \\
\text { people }\end{array}$ & $\begin{array}{l}\text { progress very } \\
\text { limited } \\
\text { partly }\end{array}$ \\
\hline $\begin{array}{l}\text { c. Raising mobility } \\
\text { - Build affordable housing } \\
\text { - Improve infrastructure } \\
\text { - Support to job search }\end{array}$ & $\begin{array}{l}\text { considered } \\
\text { partly } \\
\text { very limited }\end{array}$ & & \\
\hline
\end{tabular}

Source: Authors, based on discussions with Swazi authorities and representatives of the private sector. 


\section{b. Policies supporting young entrepreneurs}

The Government has adopted measures to support youth entrepreneurship. In 2009 it established the Youth Enterprise Fund (YEF) to fund youth start-ups. ${ }^{12}$ Access to credit is an obstacle for young entrepreneurs in Swaziland who often lack collateral experience and are thus considered 'high risk' by the commercial banks (UN Swaziland, 2013). The YEF helps address these constraints. In 2010, the fund distributed 580,000 euros to about 800 young entrepreneurs. In 2011, the Fund distributed another 200,000 euros to 200 entrepreneurs. ${ }^{13}$ However, the low repayment rates underscored the importance of strengthened proposal evaluations and better monitoring of the use of disbursed funds. The lack of skills and experience of young entrepreneurs pointed also to the need to combine funds with training.

While the YEF has been a step in the right direction, it would need to be markedly scaled up and restructured to make a dent in youth employment. Swaziland is yet to develop a comprehensive youth employment and entrepreneurship policy that would integrate its young people into the labor market and help reach inclusive growth. In that regard, international experiences with initiatives targeting youth entrepreneurship, and what has worked, can inform policy design in Swaziland:

- The study of high potential young entrepreneurs in Europe emphasized: (i) the importance of selectivity so that youth with best projects are supported; (ii) preference for more intense support per entrepreneur rather than spreading resources thinly; and (iii) integrated support packages rather than a single instrument (OECD, 2012).

- Designing and implementing the integrated service packages rather than isolated measures is also a key lesson from entrepreneurship programs in Sub-Saharan Africa that targeted vulnerable youth (Puerto, 2007). Another lesson is that in cases where the government provides start-up subsidies, it should have a credible exit strategy. Training schemes tend to be more effective when administered by the private sector which understands entrepreneurs' needs, while the government incentives are important for the uptake of these programs. ${ }^{14}$

\section{Conclusions}

This paper provided first systematic evidence on the youth employment challenge in Swaziland, based on the country's 2007 and 2010 labor force surveys as well as the authors' discussions with representatives of the private sector and policymakers. The paper documented the types of labor market disadvantages impacting youth and how they changed due to the first round impacts of the global financial crisis. It then applied multivariate analysis to uncover socio-economic factors (e.g., education, age, gender, location and mobility) driving youth labor outcomes. Since the key obstacles to addressing youth employment challenge in Swaziland are on the demand side of the labor market, we looked into

\footnotetext{
${ }^{12}$ Among NGOs, TechnoServe, has supported Swazi SMEs, including those owned by youth while the Junior Achievement Swaziland (JASD) has been developing entrepreneurial skills among Swazi high school students. Credits constraints and the lack of skills have been recognized as obstacle to entrepreneurship across Africa (Baliamoune et al., 2011 and Brixiová, 2010). These obstacles impact more heavily youth than adults.

${ }^{13}$ No collateral is required. Young entrepreneurs have up to 3 months to start their business upon receiving the funds; they have to repay loans within 24 months. Interest rate is about $10 \%$, well below the commercial rates.

${ }^{14}$ The messages are elaborated in Johanson and Van Adams (2004), Schoof (2006), Puerto (2007), and others.
} 
the main impediments to private sector development as well as lessons from the recent initiatives to stimulate youth employment and entrepreneurship in Swaziland and other countries.

Key policy messages for fostering dynamic youth entrepreneurship - in Swaziland and other middle income countries in Southern Africa -- are that an enabling business environment is only one, even though necessary, aspect. The government's pro-active support for entrepreneurial training and start-up capital is also needed. Regarding the latter, the Swaziland's experience underscored the importance of careful selection of projects for funding, and of monitoring the use of funds after disbursement. International good practices suggest that government interventions should target the most viable projects, extend greater financial support to a fewer high-potential entrepreneurs rather than spread resources thinly, and provide complementary packages of services instead of a single measure.

The topic of effective government policies encouraging youth entrepreneurship in Africa is relatively understudied and gives opportunities for high impact policy-oriented research. Further studies in this area could explore the role of African youth in technology adoption and innovation as well as different policies that the governments can adopt towards high potential and vulnerable youth groups.

The youth employment challenge is complex and successful solutions will need to draw on various stakeholders and multi-disciplinary approaches. In this paper, we have focused mostly on labor market and entrepreneurship-related policies and thus left the broader issues of an enabling youth employment framework (e.g., macroeconomic conditions, the rule of law, political leadership) as well as youth empowerment and integration into the society for further research. 


\section{Annex I - Youth and Adult Unemployment}

Table 1, Annex I. Youth and adult unemployment ratios, by gender and age sub-groups

\begin{tabular}{lcccl}
\hline & Men & Women & SE of difference & Significance \\
\hline Total unemployment & 0.2397 & 0.3029 & 0.0122 & $* * *$ \\
Adult unemployment $(25+)$ & 0.1740 & 0.2270 & 0.0124 & $* * *$ \\
Youth unemployment $(15-24)$ & 0.5010 & 0.5520 & 0.0290 & $*$ \\
Teenagers $(15-19)$ & 0.4930 & 0.5490 & 0.0592 & \\
Young Adults 1 (20 - 24) & 0.5034 & 0.5526 & 0.0333 & \\
Young Adults 2 (25 - 29) & 0.2760 & 0.3480 & 0.0316 & $* *$ \\
\hline & Youth & Adults & & \\
\hline Total unemployment & 0.5270 & 0.1950 & 0.0157 & $* * *$ \\
Male unemployment & 0.5010 & 0.1740 & 0.0222 & $* * *$ \\
Female unemployment & 0.5520 & 0.2270 & 0.0224 & $* * *$ \\
\hline
\end{tabular}

Source: Authors’ calculations based on Swaziland Labor Force Survey 2007. Note: Labor force is normalized to 1, unemployment is the ratio of the age- relevant labor force. 


\section{References}

African Development Bank, Organization for Economic Cooperation and Development, United Nations Development Program and Economic Commission for Africa (2013), African Economic Outlook 2013:Structural Transformation and Natural Resources, AfDB: Tunis; OECD: Paris; UNDP: New York; and UNECA: Addis Ababa.

African Development Bank, Organization for Economic Cooperation and Development, United Nations Development Program and Economic Commission for Africa (2012), African Economic Outlook 2012: Promoting Youth Employment, AfDB: Tunis; OECD: Paris; UNDP: New York; and UNECA: Addis Ababa.

Anyanwu, J. (2013), 'Characteristics and Macroeconomic Determinants of Youth Employment in Africa’, paper presented at the 2013 ASSA meetings (San Diego, January).

Baliamoune, M.; Brixiová, Z. and Ndikumana, L. (2011), 'Credit Constraints and Productive Entrepreneurship in Africa’, IZA Discussion Paper No. 6193, Institute for the Study of Labor: Bonn.

Brixiová, Z. (2010), 'Unlocking Productive Entrepreneurship in Africa’s Least Developed Countries, African Development Review, Vol. 22(3), 440 - 451.

Felipe, J. (2012), 'Tracking the Middle-Income Trap: What is It, Who is in It, and Why?, Asian Development Bank Working Paper Series No. 306.

Government of Swaziland (2011), Poverty Maps, Government of Swaziland: Mbabane.

Guarcello, L.; Kovrova, I. and Lyon, S. (2012), 'Youth disadvantage in the labor market: empirical evidence from nine developing countries', UNESCO Background Paper for the Education for All Global Monitoring Report, 2012/ED/EFA/MRT/PI/38.

International Labor Office (2012), Global Employment Trends for Youth 2012, ILO; Geneva.

Jauch, H. (2011), 'Time to Turn the Tide: Tackling Poverty, Inequality and Unemployment in Southern Africa’, Freidrich Ebert Stiftung Perspective (June).

JICA, World Bank and African Development Bank (2013), 'Youth Employment in Africa: Empowering Young Africans to Live their Dreams', Joint Recommendations of JICA, the World Bank and the African Development Bank at TICAD V (June).

Johanson, R. K. and Van Adams, A. (2004), Skills Development in Sub-Saharan Africa, World Bank: Washington DC.

Kangoye, T. and Brixiová, Z. (2013), 'The Gender Gap in the Labor Market in Swaziland', paper presented at the 2013 CSAE Conference (March, Oxford). 
Khumalo, T. (2011), 'Developing a Strategy for Urban Youth Employment in Swaziland', UNISWA Research Journal, Vol. 26 (December), Special issue sponsored by the Organization for Social Science Research in Eastern and Southern Africa (OSSREA), 99-113.

Kolev, A. and Sagev, C. (2005), 'Understanding Youth Labor Market Disadvantage: Evidence from South-East Europe’, International Labour Review, Vol. 144(2), 161 - 187.

Lisk, F. and Dixon-Fyle, K. (2013), 'Promoting Youth Entrepreneurship in STI-driven MSMEs: Thematic Overview', in Promoting Youth Entrepreneurship in STI-driven MSMEs, African Development Bank: Tunis.

Marope, M. (2010), The Education System in Swaziland: Training and Skills Development for Shared Growth and Competitiveness, World Bank Working Paper No. 188, African Human Development Series.

OECD (2012), Policy Brief on Youth Entrepreneurship: Entrepreneurial Activities in Europe, OECD: Paris.

Page, J. (2012), 'Youth, Jobs, and Structural Change,’ African Development Bank Working Paper No. 155.

Puerto, O. S. (2007), 'International Experience on Youth Employment Interventions: The Youth Employment Inventory’, background paper for the World Bank’s 2007 economic and sector work on 'Sierra Leone, Youth and Employment', World Bank: Washington, DC.

Scarpetta, S.; Sonnet, A. and Manfredi, T. (2010), 'Rising Youth Unemployment During The Crisis: How to Prevent Negative Long-term Consequences on a Generation?', OECD Social, Employment and Migration Working Papers, No. 106.

Schoof, U. (2006), 'Stimulating Entrepreneurship: Barriers and Incentives to Enterprise Start-Ups by Young People’, Small Enterprise Development Programme Working Paper No. 76, ILO: Geneva.

Stampini, M. and Verdier-Chouchane, A. (2011), 'Labor Market Dynamics in Tunisia: The Issue of Youth Unemployment’, Middle East Review of Economics and Finance, Vol. 7 (2), 1- 35.

Swaziland Ministry of Labor and Social Security (2008), Integrated Labor Force Survey 2007, Mbabane, Swaziland.

UNDP (2013), Human Development Report 2013: The Rise of the South, UNDP: New York.

United Nations Swaziland (2013), Opportunities and Constraints to Youth Entrepreneurship: Perspectives of Young Entrepreneurs in Swaziland, UN Swaziland: Mbabane (January).

United Nations Swaziland (2012), Rapid Assessment of the Impact of the Fiscal Crisis in Swaziland, UN Swaziland: Mbabane (March).

White, S. and Kenyon, P. (2000). 'Enterprise-based Youth Employment Policies, Strategies and Programs’, ILO, Geneva. 
World Bank (2013a), World Development Report 2013: Jobs, World Bank: Washington, DC.

World Bank (2013b), Doing Business 2013: Smarter Regulations for Small and Medium-Sized Enterprises, World Bank: Washington, DC.

World Bank (2013c), Youth Employment in Sub-Saharan Africa: Overview, World Bank: Washington, DC. 


\section{DAVIDSON INSTITUTE WORKING PAPER SERIES - Most Recent Papers}

The entire Working Paper Series may be downloaded free of charge at: www.wdi.umich.edu

CURRENT AS OF $\quad 07 / 10 / 13$

\begin{tabular}{|c|c|c|}
\hline Publication & Authors & Date \\
\hline $\begin{array}{l}\text { No. 1052: YOUTH EMPLOYMENT IN AFRICA: NEW EVIDENCE AND POLICIES } \\
\text { FROM SWAZILAND }\end{array}$ & $\begin{array}{l}\text { Zuzana Brixiova and Thierry } \\
\text { Kangoye }\end{array}$ & June 2013 \\
\hline No. 1051: Oil Windfalls, Fiscal Policy and Money Market Disequilibrium & $\begin{array}{l}\text { Salman Huseynov, Vugar } \\
\text { Ahmadov }\end{array}$ & June 2013 \\
\hline No. 1050: Price Jump Indicators: Stock Market Empirics During the Crisis & $\begin{array}{l}\text { Jan Novotný, Jan Hanousek, and } \\
\text { Evžen Kočenda }\end{array}$ & June 2013 \\
\hline $\begin{array}{l}\text { No. 1049: Impact of Financial Deregulation on Monetary \& Economic } \\
\text { Policy in the Czech Republic, Hungary and Poland: } 1990-2003\end{array}$ & Patricia McGrath & May 2013 \\
\hline $\begin{array}{l}\text { No. 1048: The 90\% Public Debt Threshold: The Rise \& Fall of a Stylised } \\
\text { Fact. }\end{array}$ & Balázs Égert & May 2013 \\
\hline $\begin{array}{l}\text { No. 1047: The efficiency and equity of the tax and transfer system in } \\
\text { France }\end{array}$ & Balázs Égert & April 2013 \\
\hline No. 1046: Optimal Resource Rent & Rustam Jamilov & Mar 2013 \\
\hline $\begin{array}{l}\text { No. 1045: Financial Development and Economic Growth: } \\
\text { A Meta-Analysis }\end{array}$ & $\begin{array}{l}\text { Petra Valickova, Tomas Havranek } \\
\text { and Roman Horvath }\end{array}$ & Mar 2013 \\
\hline No. 1044: Incomplete Specialization \& Trade in Parts \& Components & $\begin{array}{l}\text { Richard Frensch, Jan Hanousek \& } \\
\text { Evzen Kocenda }\end{array}$ & Mar 2013 \\
\hline $\begin{array}{l}\text { No. 1043: Tax evasion, tax corruption and stochastic } \\
\text { growth }\end{array}$ & $\begin{array}{l}\text { Fred Célimène, Gilles Dufrénot, } \\
\text { Gisèle Mophou, and Gaston } \\
\text { N.Guérékata }\end{array}$ & Feb 2013 \\
\hline $\begin{array}{l}\text { No. 1042: Public debt, economic growth and nonlinear effects: Myth or } \\
\text { reality? }\end{array}$ & Balázs Égert & Feb 2013 \\
\hline $\begin{array}{l}\text { No. 1041: Interest Rate Pass-Through and Monetary Policy Asymmetry: } \\
\text { A Journey into the Caucasian Black Box }\end{array}$ & $\begin{array}{l}\text { Rustam Jamilov and } \\
\text { Balázs Égert }\end{array}$ & Feb 2013 \\
\hline No. 1040: Myths about Beta-Convergence & Konstantin Gluschenko & Nov 2012 \\
\hline $\begin{array}{l}\text { No. 1039: South East Asian Monetary Integration: New Evidences from } \\
\text { Fractional Cointegration of Real Exchange Rates }\end{array}$ & $\begin{array}{l}\text { Gilles de Truchis and } \\
\text { Benjamin Keddad }\end{array}$ & Oct 2012 \\
\hline No. 1038: Transmission Lags of Monetary Policy: A Meta-Analysis & $\begin{array}{l}\text { Tomas Havranek \& } \\
\text { Marek Rusnak }\end{array}$ & Oct 2012 \\
\hline $\begin{array}{l}\text { No. 1037: The Dynamics of the Regulation of Labor in Developing and } \\
\text { Developed Countries since } 1960\end{array}$ & $\begin{array}{c}\text { Nauro Campos and } \\
\text { Jeffrey Nugent }\end{array}$ & Sept 2012 \\
\hline $\begin{array}{l}\text { No. 1036: Sovereign Wealth Fund Issues and The National Fund(s) of } \\
\text { Kazakhstan }\end{array}$ & David Kemme & $\begin{array}{l}\text { August } \\
2012\end{array}$ \\
\hline $\begin{array}{l}\text { No. 1035: Stock Market Comovements in Central Europe: Evidence from } \\
\text { Asymmetric DCC Model }\end{array}$ & Dritan Gjika and Roman Horvath & $\begin{array}{l}\text { August } \\
2012\end{array}$ \\
\hline $\begin{array}{l}\text { No. 1034: Regional Motives for Post-Entry Subsidiary Development: } \\
\text { The Case of Poland }\end{array}$ & $\begin{array}{l}\text { Agnieszka Chidlow, Christine } \\
\text { Holmstrom-Lind, Ulf Holm \& } \\
\text { Heinz Tuselmann }\end{array}$ & June 2012 \\
\hline $\begin{array}{l}\text { No. 1033: The Effects Of Network's Structural Holes: Polycentric } \\
\text { Institutions, Product Portfolio, And New Venture Growth In China And } \\
\text { Russia }\end{array}$ & Bat Batjargal & May 2012 \\
\hline $\begin{array}{l}\text { No. 1032: The Bulgarian Foreign and Domestic Debt - A No-Arbitrage } \\
\text { Macrofinancial View }\end{array}$ & Vilimir Yordanov & $\begin{array}{l}\text { March } \\
2012\end{array}$ \\
\hline
\end{tabular}

